1999

\title{
The Universal and the Particular in International Criminal Justice
}

Ruti Teitel

New York Law School

Follow this and additional works at: http://digitalcommons.nyls.edu/fac_articles_chapters

Part of the Criminal Law Commons, and the International Law Commons

\section{Recommended Citation}

30 Colum. Hum. Rts. L. Rev. 285 (1998-1999)

This Article is brought to you for free and open access by the Faculty Scholarship at DigitalCommons@NYLS. It has been accepted for inclusion in Articles \& Chapters by an authorized administrator of DigitalCommons@NYLS. 


\title{
THE UNIVERSAL AND THE PARTICULAR IN INTERNATIONAL CRIMINAL JUSTICE
}

\author{
by Ruti Teitel*
}

\section{INTRODUCTION}

The beginning of the modern moment is identified by at least one philosopher in the response to the Lisbon earthquake in $1755 .{ }^{1}$ Rather than merely accepting the catastrophe as misfortune or fate, a new response emerged: the disaster was characterized as "injustice," a failure of human, not divine, intervention. In this about-face, the deadly consequences of the Lisbon earthquake were seen as the result of a failure of human action; the insecure architecture of the city's apartment buildings was the fault line to blame.

A similar adoption of the language of justice characterized the modern human rights movement, which commenced in the response to World War II. This international response was noteworthy for its legal character; it emphasized criminal accountability, its symbols the International Military Tribunal and the Nuremberg proceedings. Indeed, the ongoing legacy of the postwar response is evinced in the contemporary moment. As we near the century's end, the recurring manifestations of the call for the protection of international human rights are persistently and overwhelmingly criminal in nature: the convening of the Hague Tribunals for the former Yugoslavia and Rwanda, ${ }^{2}$ the entrenchment of the Nuremberg-style International Criminal Court in the recent Rome agreement, ${ }^{3}$ as well as the transnational proceedings initiated against General Augusto Pinochet, the former Chilean dictator. ${ }^{4}$ Contemporary responses to tragic atrocities identify criminal accountability in the international legal system with the rule of law.

This Article explores contemporary developments in international human rights in analyzing the emergence of international criminal law as an arch response to atrocity in the name of human rights. A critical question

\footnotetext{
* Ernst C. Stiefel Professor of Comparative Law, New York Law School.

1. See Judith N. Shklar, The Faces of Injustice 51-54 (1990).

2. See infra note 35 .

3. See infra note 7.

4. See infra note 31 .
} 
raised by this response is, what are the aims of international criminal law in its advancement of human rights? If international criminal justice is intended to protect human rights, to what extent is its role the accurate representation of and retribution for past wrongs? Or is its role to transform societal understandings in advancing the protection of human rights? And if the latter, how exactly do criminal processes effect the liberal transformation of transitional states emerging from authoritarian rule?

There appear to be two alternative normative paradigms advanced by the use of international criminal law: "politics of universalism" and "politics of difference." A universalistic politics drives the postwar paradigm, in which both principles of jurisdiction and substantive criminal law are shaped by a standard of "humanity." Challenging the historical universalist paradigm is a more contemporary paradigm, which advances an identity politics. In the politics of difference, international criminal law moves beyond the conventional role of criminal justice of isolating individual wrongdoing to emphasize the representation of individual victims and their persecution on the basis of group affiliation. In contemporary proceedings, international criminal law both affirms individual rights to equal protection, and through its considerations of policy, also represents the collective. As is elaborated more fully below, these alternative paradigms are in some tension. This is apparent in how the purposes and role of international criminal law mediate the universal and the particular. Ultimately, contemporary attempts to model a coherent conception of international criminal justice culminate in a chiefly limited process-based conception of the rule of law.

What is international criminal law's potential for advancing human rights? To what extent can the difficult project of transformation, of moving to a more liberal politics, be accomplished through international criminal processes? This Article explores various paradigms of international criminal justice with an eye to a better understanding of the potential of criminal law in the contemporary moment.

\section{ThE POLITICS OF UNIVERSALISM}

Consider the genealogy of modern human rights law. Historically, international criminal institutions and processes have been dedicated to representing the universal in human rights. As the prevailing scholarly accounts suggest, the beginning of the modern international human rights movement occurred in the postwar period, with the Universal Declaration of 
Human Rights following closely the establishment of the International Military Tribunal at Nuremberg. ${ }^{5}$ Moreover, these understandings of human rights as universal share affinities with the constitutional developments that accompanied the beginning of the international human rights movement. ${ }^{6}$

The International Military Tribunal at Nuremberg has long been a potent symbol of law's universality. The nature of the proceedings, the substantive charges brought and adjudicated, in particular "crimes against humanity" as defined in the Nuremberg Charter, and the subsequent trials all embodied understandings of universal standards of humanity. ${ }^{7}$ A central

5. Universal Declaration of Human Rights, Dec. 10, 1948, G.A. Res. 217A, U.N. GAOR, 3d Sess., U.N. Doc. A/810 (1948); Charter of the International Military Tribunal, Aug. 8, 1945, art. 1, 59 Stat. 1544, 1546, 82 U.N.T.S. 279, 284.

6. See Louis Henkin, The Age of Rights 16-17 (1990) (observing that human rights began appearing in constitutions during the postwar period and that "universalization" is reflected in national constitutions).

7. Compare Allied Control Council Law No. 10, Punishment of Persons Guilty of War Crimes, Crimes Against Peace and Against Humanity, Dec. 20, 1945, reprinted in 1 Benjamin B. Ferencz, An International Criminal Court: A Step Toward World Peace 488 (1980), with Charter of the International Military Tribunal, supra note 5, art. 6(c). Article 6 (c) of the Nuremberg Charter defines "crimes against humanity" as

murder, extermination, enslavement, deportation, and other inhumane acts committed against any civilian population, before or during the war, or persecutions on political, racial or religious grounds in execution of or in connection with any crime within the jurisdiction of the Tribunal, whether or not in violation of the domestic law of the country where perpetrated.

Charter of the International Military Tribunal, supra note 5, art. $6(\mathrm{c})$.

Article 7 of the recent Rome Statute of the International Criminal Court expands the definition of "crimes against humanity":

[T] he following acts when committed as part of a widespread or systematic attack directed against any civilian population, with knowledge of the attack: (a) Murder; (b) Extermination; (c) Enslavement; (d) Deportation or forcible transfer of population; (e) Imprisonment . . .; (f) Torture; (g) Rape, sexual slavery . . .; (h) Persecution against any identifiable group or collectivity on political, racial, national, ethnic, cultural, religious, gender . . . grounds . . .; (i) Enforced disappearance of persons; (j) The crime of apartheid; and (k) Other inhumane acts of a similar character ....

Rome Statute of the International Criminal Court, U.N. Diplomatic Conference of Plenipotentiaries on the Establishment of an International Criminal Court, art. 7, U.N. Doc. 
charge at Nuremberg was "crimes against humanity," proscribing inhumane acts committed against civilians, whether or not in the context of the war. ${ }^{8}$ Despite the enormity of the war, the Tribunal's normative legacy is one of the core concepts of universal human dignity. ${ }^{9}$

Though the commitment was to the advancement of "universal" values, the natural law theory animating the postwar legal responses-whether in their criminal or their constitutional form-was tempered by the various legal and political traditions prevailing in the postwar period. In part, the relevant traditions derived from the circumstances of the Allied response to Nazi Germany. Accordingly, what was deemed "universal" at the time was informed by Allied traditions and by the explicit, critical response to repressive fascism. Accordingly, law's response and its turn to the universal reflected the then-reigning view that the perversion of Nazi rule derived from moral relativism implicit in that regime's understanding of legality. The repression of the Nazi regime was associated with its putative positivist philosophy of law. ${ }^{10}$ Accordingly, the direct response to totalitarianism was the move to natural law concepts implicated by the universal rights violations adjudicated in the international proceedings that were convened. This conception of universal human rights also reflected the ascendance of American rights traditions in postwar occupied Europe. Both the then-emerging international human rights movement and the wave of constitutionalism shared a common theory of rights: rights conceptualized as traditional Anglo-American rights at law, that is, rights as norms backed by sanctions. ${ }^{11}$

On this account, the postwar procedures are best understood as concretizing both a particular view of rights, a conception that was a product of its times, and the belief in modernity and law. Postwar justice was conceived of as a system of judicially enforced rights. Whereas traditionally the predicate to enforceable rights was a functioning nation-state, however,

A/CONF.183/9 (1998) [hereinafter Rome Statute].

8. See generally Telford Taylor, The Anatomy of the Nuremberg Trials (1992).

9. See Ruti Teitel, Nuremberg and Its Legacy, Fifty Years Later, in War Crimes: The Legacy of Nuremberg 44 (Belinda Cooper ed., 1999).

10. Though scholars of the period suggest the judiciary's philosophy of law under the Reich was considerably more complicated. See, e.g., Ingo Müller, Hitler's Justice: The Courts of the Third Reich 68-81 (Deborah Lucas Schneider trans., Harvard Univ. Press 1991); Ruti Teitel, Transitional Jurisprudence: The Role of Law in Political Transformation, 106 Yale L.J. 2009, 2025 \& n.52 (1997).

11. See H.L.A. Hart, The Concept of Law 218 (Clarendon Press 1994) (1961). 
the postwar responses exemplified the landmark uses of a new legal system by internationalizing a traditional, domestic form of rights protection through judicial processes. The modern international human rights regime sought to construct human rights as universal by casting individual rights and responsibilities in terms of universalizing human characteristics. The adjudication of human rights violations in the "crimes against humanity" proceedings in a manner that encompassed natural law understandings demonstrates this phenomenon. ${ }^{12}$

Nevertheless, it is important to recognize the extent to which the asserted universalist conception of human rights is animated by and contingent upon its particular political context. Despite pretensions to universality, the wartime political context had a pervasive and ongoing force; it operated as a substantive restrictive principle, limiting the Tribunal's jurisdiction. Thus, prosecutions in the Nuremberg proceedings were limited to inhumane acts with a demonstrable nexus to war. ${ }^{13}$ Even under the rubric of universality, the understanding of human rights is limited in multiple respects. For example, where "universal" offenses are adjudicated in the domestic context, these adjudications are constrained by conventional jurisdictional principles such as territoriality nationality.

The postwar conception of the judicialized human rights model persists to the present day. That protection of human rights is still thought to be attainable through international punishment processes shows the continuing dominance of the postwar paradigm and its central symbols. Nevertheless, such criminal proceedings have been few and far between, despite numerous genocidal campaigns and the commission of other atrocities in this century. The adjudication of genocide has largely been limited to the Nuremberg trials ${ }^{14}$ and the more contemporary atrocities relating to the Balkans conflict. Indeed, the international proceedings that were convened as a result of ethnic cleansing in Europe, the International Criminal Tribunal for the Former Yugoslavia, was the first such effort since the World War II-related trials. ${ }^{15}$ The sporadic application of the Genocide

12. See Judith N. Shklar, Legalism: Law, Morals, and Political Trials (2d ed. 1986).

13. For a discussion of this prudential self-limiting in the scope of the postwar trials, see Taylor, supra note 8, at 113-15.

14. See Beth Van Schaack, The Crime of Political Genocide: Repairing the Genocide Convention's Blind Spot, 106 Yale L.J. 2259, 2259 (1997).

15. See infra note 38 . 
Convention ${ }^{16}$ and the failure to adjudicate cases of political genocide ${ }^{17}$ relate to a distinctive postwar history. The general lack of rights enforcement by means of criminal proceedings contributes to a pervasive sense that the international human rights regime is flawed, even as it also suggests that the judicial, procedural feature of the universal conception of rights retains ongoing significance today.

\section{The MOVE TO Politics OF DIFFERENCE}

The move away from the notion of a unitary, universalizing conception of human rights to a broader understanding that comprehends a more complex understanding of identity began, paradoxically, with the Cold War. The political realities of the period led to rights differentiation and the attempt to draw distinctions among rights, in particular between political and civil as opposed to economic and social rights. A debate emerged about the meaning of "real" human rights, challenging the postwar rights model. The debate reflected the existence of normative dissent not apparent at the beginning of the human rights movement. The conflicts focused in particular on the conception of the state and the extent of its commitments to and agenda regarding economic security. Despite the assertion of the equivalence of political and economic rights in the Universal Declaration of Human Rights, the rights divide was stark, as seen in bitter debates in the United Nations, ${ }^{18}$ as well as in the ultimate adoption of separate covenants to enforce political and economic rights. ${ }^{19}$ Moreover, the dominance of the judicialized rights paradigm further obscured the comparability of these rights. Rights differentiation challenged the prevailing rights model insofar as the model had emphasized the protection, through judicial processes and apparatuses, of political norms considered universal. This challenge to the postwar rights model, raising issues of enforceability as well as the purported

16. See Convention on the Prevention and Punishment of the Crime of Genocide, Dec. 9, 1948, 78 U.N.T.S. 277 (entered into force Jan. 12, 1951).

17. See Van Schaack, supra note 11, at 2269-72.

18. See generally Seminar on the Realization of Economic and Social Rights contained in the Universal Declaration of Human Rights, at 5-13, U.N. Doc. ST/TAO/HR/31 (1967).

19. See Intemational Covenant on Civil and Political Rights, opened for signature Dec. 19, 1966, 999 U.N.T.S. 171 (entered into force Mar. 23, 1976); International Covenant on Economic, Social and Cultural Rights, opened for signature Dec. 19, 1966, 993 U.N.T.S. 3 (entered into force Jan. 3, 1976). 
antinomy regarding so-called "positive" and "negative" rights, went to the very meaning of international human rights. Understandings of the justiciability and enforcement of rights ordinarily associated with domestic law played a significant role in defining rights on the international scene. ${ }^{20}$ Ultimately, an apparent rights hierarchy emerged, with a rights conception considered so different from the first wave in the postwar period that it has been readily understood to comprise another "generation" of rights. ${ }^{21}$

Contemporary adjudications of international human rights violations in the courts show a more complex view of the second generation rights model. These proceedings reflect a move away from the postwar search for universal definitions and values to particularist human rights norms, understandings that are linked to particular national contexts and political conflicts. In a number of countries, the struggle over whether and how to limit the application of the concept of "universality" in the postwar human rights regime went hand in hand with related limiting jurisdictional principles based on particularist notions of identity, such as nationality and ethnicity. Whereas offenses at Nuremberg were prosecuted as "crimes against humanity" on a universalizing basis, in the subsequent national trials of the 1950s and 1960s these offenses were prosecuted in terms of the collective. ${ }^{22}$ This change was not necessarily embraced. ${ }^{23}$

The shift to a particularized notion of rights marks a number of deliberations over adjudicating the "crime against humanity" offense within national jurisdictions throughout Europe. In the 1960s, a debate ensued in Germany over whether, and in what fashion, to continue the World War IIrelated trials. Once again, this debate revealed the tension in international criminal law between the universal and the particular, juxtaposing universalizing ideas of jurisdiction against more particular notions of justice

20. See Maurice Cranston, What Are Human Rights? 84-85 (1962).

21. See Louis B. Sohn, The New International Law: Protection of the Rights of Individuals Rather Than States, 32 Am. U. L. Rev. 1, 32 (1982) (distinguishing the first generation of rights, civil and political rights, from economic, social, and cultural rights, which comprise the second generation).

22. In Israel, for example, Eichmann was prosecuted for commission of "crime[s] against the Jewish people." See Cr.C. (Jm.) 40/61 Attorney General of Israel v. Eichmann, 1961, reprinted in 56 Am. J. Int'l L. 805 (1962).

23. For example, for some scholars the representation in the trial of Adolf Eichmann of a more contextualized account of the wartime atrocities as committed "against the Jewish people" was incomplete. See, e.g., Hannah Arendt, Eichmann in Jerusalem: A Report on the Banality of Evil 275-76 (Penguin Books 1994) (1963). 
as resolved in national statutes of limitations. Ultimately, the wartime-era trials were continued, but with significant limits. Indeed, the salient restrictive principles included status-for example, nationality of the parties-and motive. While jurisdictional principles are often considered largely procedural, in the international arena these principles express critical normative values; they illuminate the nature of the relation of law to politics and help explicate what norms might transcend a state's transient political consensus.

In another European trial for World War II-related atrocities, the prosecution in France of Klaus Barbie in the late 1980s for wartime deportations of civilians raised again the extent to which asserted universal human rights are reconcilable with national traditions and legal cultures. In the 1960s, France incorporated the Nuremberg definition of "crimes against humanity" into its criminal law-a domestic, national law incorporation of concepts of universality. ${ }^{24}$ The incorporation of international standards into national law had important ramifications. Applying the principle of universal jurisdiction implied by wronging "humanity" created tension with preexisting limiting principles of jurisdiction, and therefore necessitated changing fundamental jurisdictional principles. For purposes of the "crime against humanity," the twenty-year time limit that would ordinarily have applied to all offenses in France, no matter how heinous, was tolled, allowing the prosecution of Barbie for World War II offenses to go forward in 1987. This case illustrates the extent to which prosecutions of war crimes, even years after the fact, continue to be shaped by a state's particular legal culture and the ambient political circumstances.

International jurisdiction offers a space for the representation of human rights values. Adjudicating "crimes against humanity" implies displacing the domestic law principles that would ordinarily constrain prosecution and signals an attempt to denationalize and depoliticize, and hence universalize, the relevant offenses. Yet, notwithstanding the passage of time, depoliticizing the prosecution of wartime crimes of the Vichy regime proved difficult. Despite the attempt to reconcile universal criminal justice within a national regime, crimes are adjudicated within the parameters of a distinct political context, jurisdiction, and related principles. While the adjudication of "crimes against humanity" historically implied features of normative universalism, its treatment in the Barbie trial in contemporary France ultimately represented another politics-identity

24. See C. Pén., arts. 211-1, 212-1 (Fr.). 
politics. ${ }^{25}$ Political differences over the trial emerged in a partisan debate in France, the broad contours of which were historical. The controversy centered around the meaning of "crimes against humanity" as incorporated in French law: namely, whether the prosecution of crimes against humanity could go beyond the atrocities committed against "innocent Jews" to include those committed against members of the Resistance. ${ }^{26}$ In its review, France's High Court moved beyond the status-based conceptualization of protected classes to a more complex understanding of the scope of the "humanity" crime, focusing not on the victims' status but on the perpetrators' motives in behavior against the backdrop of state policy. ${ }^{27}$ Yet when policy predominated, leading to expansion of the humanity charge to include crimes against members of the Resistance, the move appeared politically motivated and was controversial in the country, opening a debate about the subjects of the humanity crime. ${ }^{28}$ The national cases adjudicating "crimes against humanity" reinterpreted the term's meaning in the context of the changing rights regime.

The emergence of a third generation of rights, rights that comprehend collectives and ethnicity rights, marks the more recent developments. ${ }^{29}$ Conferring the imprimatur of international law on communities defined along ethnic and religious lines challenged the hitherto normative emphasis on the universal in human rights. The move from considerations of status to those of individual action ultimately refocuses attention on policy, linking the individual to the collective.

25. See Guyora Binder, Representing Nazism: Advocacy and Identity at the Trial of Klaus Barbie, 98 Yale L.J. 1321, 1381 (1989).

26. See Fédération Nationale des Déportés et Internés Résistants et Patriotes and Others v. Barbie, 78 I.L.R. 125, $139-40$ (Fr., Cass. crim., Dec. 20, 1985).

27. Id.

28. See Alain Finkielkraut, Remembering in Vain: The Klaus Barbie Trial and Crimes Against Humanity 19-20 (Roxanne Lapidus \& Sima Godfrey trans., Columbia Univ. Press 1992).

29. See Sohn, supra note 21 , at 48 . 


\section{HUMAN RIGHTS GLOBALIZATION}

In the contemporary moment, international human rights norms have "gone global"; their protection is envisioned as somehow autonomous, no longer bounded by international institutions or even the affected nationstates. Contemporary instantiations of international criminal justice seem to operate independent of conventional connections such as territoriality, effects, or nationality, whether of offender or victim. ${ }^{30}$ The expansion beyond these traditional bases for jurisdiction suggests new directions for normative principles for assuming jurisdiction. On their face, rights norms appear to be developed in an unsystematic manner. Jurisdiction is often taken or assumed by states with apparently remote connections to the underlying controversy, in the name of human rights.

Accordingly, the contemporary emergence of rights globalization is highlighted not only by the ad hoc international tribunals for the former Yugoslavia and Rwanda, but also by occasional national cases, such as Spain's extradition request of General Pinochet for human rights violations perpetrated in Chile under military rule. ${ }^{31}$ In addition, Germany indicted Dusko Tadic for commission of war crimes in the Balkans prior to turning him over to the International Tribunal. ${ }^{32}$ The assumption of jurisdiction on the basis of "crimes against humanity" jurisdiction appears to constitute an act of solidarity. Normative instantiation, in the name of human rights, is being promoted independent of the affected states, in the name of global rule of law and justice. The contemporary globalization of rights enforcement, albeit in sporadic adjudications, challenges both the immediate postwar emphasis on international institutions as well as more particularist, local understandings of justice.

30. There are traditional jurisdictional principles that connect states to criminal prosecution. See Restatement (Third) of Foreign Relations Law of the United States $\S 402$ (1987). The Comment to section 402 provides that a state has jurisdiction to prescribe law under general principles of: (1) territoriality; (2) nationality; (3) effects within the territory; (4) protection of the state's security; (5) passive personality. Id. cmts. a-g.

31. See In Re Pinochet, Opinions of the Lords of Appeal for Judgment in the Cause (Jan. 15, 1999) (visited Feb. 6, 1999) <http://www.parliament.the-stationeryoff...pa/ld199899/ldjudgmt/jd990115/pino01.htm>.

32. See The Prosecutor v. Dusko Tadic a/ka "Dule," Case No. IT-94-1-T, Opinion and Judgment, pt. I.B., 17 6-9 (May 7, 1997) (visited May 11, 1999) <http://www.un.org/ icty/tadic/trialc2/jugement-e/970507jt.htm>. 
Human rights globalization through international criminal law enforcement suggests a profound change in the sources, content, and form of rights norms. ${ }^{33}$ The enforcement of international human rights norms through judicial proceedings that occur outside the traditional spaces of contestation vividly demonstrates this change. To some extent, these adjudications signal the universal in human rights, but they also generate complex issues as the concept of universality interacts with the legal traditions and political agreements of particular countries, pointing to a changing relationship among law, politics, and justice in the international arena.

Globalization has paradoxical ramifications for international criminal justice. In some sense, it implies closer connections between countries' criminal justice systems, as reflected in the adoption of conventions and extradition treaties that facilitate transnational cooperation. At the same time, there is a change in traditional understandings of sovereignty with respect to its relation to law. As the bounds of traditional sovereignty are penetrated, expansion of criminal jurisdiction would appear to follow. Yet globalization also implies other contemporary changes that point in another direction: toward the breakdown in conventional ideas of causation, agency, and relatedly, individual responsibility. ${ }^{34}$ Systematic repression implies more than individual responsibility; indeed, at the level of the collective and the regime, it often implies that more than one regime is responsible. Although jurisdiction over international human rights violations may well be expanded as a theoretical matter, its application is stressed by other developments. The principle of individual responsibility at the core of postwar international criminal justice cannot adequately take account of systematic repression. Accordingly, globalization in rights enforcement puts great pressure on the postwar judicial rights model, spurring the further elaboration of various restrictive principles, which delimit the potential for the construction of human rights in and through the criminal law.

33. Similar developments are seen in the globalization of the civil sanctions instantiating human rights law. See Proposals of the Hague Conference and their Effect on Efforts to Enforce International Human Rights Through Adjudication (submitted by Int'l Assoc. of Democratic Lawyers), in Work Doc. No. 117, Hague Conference on Private International Law, Nov. 13, 1998.

34. See Samuel Scheffler, Individual Responsibility in a Global Age, in Contemporary Political and Social Philosophy 219, 228-29 (Ellen Frankel Paul et al. eds., 1995). 


\section{MEDIATING THE UNIVERSAL AND THE PARTICULAR IN INTERNATIONAL CRIMINAL LAW}

Consider the role of international criminal justice in responding to the grave political violence that has characterized much of the twentieth century. International criminal justice is thought to have a normative role in responding to illiberal identity politics-law is thought the apt response to communal violence and disorder. International criminal justice's normative potential is evident in the ongoing trials at the Hague, where criminal justice is being used both to respond to "ethnic cleansing" in the Balkans and Rwanda and to reconcile the conflicts in these areas. The new international criminal law statutes, whether the ad hoc codifications being applied in the Hague Tribunals for the former Yugoslavia and Rwanda ${ }^{35}$ or the statute for the proposed permanent International Criminal Court, ${ }^{36}$ involve various constructs that attempt to bridge the universal and the particular in identity politics.

With respect to the Balkans, the goal of the tribunal was profoundly ambitious: to move from communal conflict to establish peace and the rule of law, ${ }^{37}$ whereby punishment under the law would hold individuals

35. Statute of the Intemational Tribunal [for the Prosecution of Persons Responsible for Serious Violations of International Humanitarian Law Committed in the Territory of the Former Yugoslavia], Annex to Report of the Secretary-General Pursuant to Paragraph 2 of Security Council Resolution 808 (1993), U.N. SCOR, 48th Sess., Supp. for Apr.-June 1993, at 134-38, U.N. Doc. S/25704 (1993) [hereinafter ICTY Statute].

Statute of the International Tribunal for Rwanda [for the Prosecution of Persons Responsible for Genocide and Other Serious Violations of International Humanitarian Law Committed in the Territory of Rwanda and Rwandan Citizens Responsible for Genocide and Other Such Violations Committed in the Territory of Neighbouring States], Annex to S.C. Res. 955, U.N. SCOR, 49th Sess., 3453d mtg. at 15, U.N. Doc. S/RES/955 (1994) [hereinafter ICTR Statute].

36. See Rome Statute, supra note 7.

37. The Security Council's decision to establish the International Tribunal for the Former Yugoslavia (later expanded to include Rwanda) was motivated not only by an intent to punish and to prosecute, see Final Report of the Commission of Experts Established Pursuant to Security Council Resolution 780 (1992) ๆโ 3-4, Annex to Letter Dated 24 May 1994 from the Secretary-General to the President of the Security Council, U.N. Doc. S/1994/674 (1994) [hereinafter Final Report], but also as a measure to bring about peace. See Report of the Secretary-General Pursuant to Paragraph 2 of Security Council Resolution 808 (1993), 48th Sess., Supp. for Apr.-June 1993, f7 10, 22, U.N. Doc. S/25704 (1993); S.C. Res. 808, U.N. SCOR, 48th Sess., 3175th mtg. at 28, U.N. Doc. S/RES/808 (1993). This use of judicial proceedings to bring about peace had no precedent in the 
responsible in an effort to limit private vengeance. When a U.N. Commission of Experts found that there was a campaign of "ethnic cleansing," establish individual accountability to break supposed cycles of ethnic retribution. In the words of the Tribunal's prosecutor, "[a]bsolving nations of collective guilt through the attribution of individual responsibility is an essential means of countering the misinformation and indoctrination which breeds ethnic and religious hatred." 39 To that end, crimes against humanity were defined to encompass widespread and systematic inhumane acts "directed against any civilian population" including "persecutions on political, racial and religious grounds." ethnical, racial or religious group" could be shown, persecution was also prosecutable as "genocide." 41

The international proceedings at the Hague raised the question of whether the tribunals were up to the task of constructing a norm responsive to ethnic persecution. Universalist ideas were extended far beyond the postwar consensus. Thus, crimes against humanity-whether or not committed in the course of international armed conflict-were prosecuted independent of state lines. This was most vividly demonstrated in the adjudication of the attempted genocide of approximately one million Tutsi and Hutu moderates in Rwanda. The persecution was committed entirely in that country's internal conflict, and yet these crimes were adjudicated in an international forum. ${ }^{42}$ In these proceedings, universalist norms appear to have transcended traditional limits on adjudicating international offenses.

In their conventional role, the strength of criminal proceedings is that they bring out the significance of individual action, which advances principles of liberalism. The criminal law's focus on individual responsibility represents an important liberal principle: the significance of

postwar paradigm.

38. See Annex IV, The Policy of Ethnic Cleansing 17, 21-36, in Annexes to the Final Report of the Commission of Experts Established Pursuant to Security Council Resolution 780 (1992), Vol. I, U.N. Doc. S/1994/674/Add.2(Vol.I)/Annex IV (1994).

39. See Response to the Motion of the Defence on the Jurisdiction of the Tribunal at 23, (filed July 7, 1995), The Prosecutor v. Dusko Tadic a/k/a "Dule," Case No. IT-94-IT.

40. See ICTY Statute, supra note 35, art. 5.

41. See id. art. 4, \2. See also Final Report, supra note 37, \182 (concluding that the actions perpetrated in Opština Prijedor against non-Serbs would likely be confirmed in court as constituting genocide).

42. See ICTR Statute, supra note 35. 
agency and responsibility. Nevertheless, such emphasis on ascribing individual accountability in war crimes trials is of questionable value because individual proceedings ultimately obscure the profound role of systemic policy in repression. Because of their emphasis on individual accountability and because they are "bottom up," contemporary war crimes trials show a notable evasion of politics. Accordingly, international and global adjudications ultimately obscure the significance of systemic persecution. For example, since the construct of a crime against humanity highlights the universal in the offense, when persecution is adjudicated at the Hague Tribunal as an offense against the entire international community, it is construed in a profoundly apolitical way. Further, where the proceedings are convened in a political vacuum, apparently independent of traditional national jurisdictions, the criminal proceedings obscure the significance of state policies and other structural causes behind these crimes. ${ }^{43}$ In contemporary international criminal law, the constructs of "genocide" and "crimes against humanity" incorporate highly nuanced understandings of the individual and the collective. By their very definitions, these offenses link the individual and the collective. Offenses against groups incorporate a conception of cultural and ethnic identity into the definition of the offense, and individuals are prosecuted for committing such offenses. Thus, for example, the contemporary trials at the ad hoc tribunals at the Hague take note of ethnicity through principles that emphasize persecutory motive, if only to transcend it.

These contemporary criminal constructs raise again the question posed earlier in this Article of what our intuitions are regarding the appropriate purposes of international criminal law. To what extent do we expect it to simply represent past wrongdoing; or to what extent is it intended to be transformative of that past wrongdoing? In this regard, contemporary human rights proceedings risk emphasizing ethno-conscious elements of persecution that, to some extent, would affirm, and perhaps even in some small way reenact, past persecution. ${ }^{44}$ The normative change in the nule of law is thought to be a twofold symbol of equality of protection: that

43. On structural causes see Robert W. Gordon, Undoing Historical Injustice, in Justice and Injustice in Law and Legal Theory 35 (Austin Sarat \& Thomas R. Kearns eds., 1996).

44. For discussion of the performative in legal responses, see Judith Butler, Excitable Speech: A Politics of the Performative 43-44 (1997). 
is, of equal application of the law both to perpetrators and to victims-and hence all citizens in the society.

Nevertheless, the universal and the particular are somehow in tension here. While new law affirms and seemingly protects individual rights, the motive principle plays a restrictive role, limiting the reach of the offense as against humanity and sharply constraining the application of international law. This results from the often crushing burden of proof, making prosecution difficult. Moreover, the insistence on proof of individual motive can be misleading, as it obscures the extent to which persecutory policy is a social and above all political construct. The parameters of this potentially universalizing construct undermine the possibility of adequately representing the extent to which the architecture of genocide is political. ${ }^{45}$

\section{MILLENNIAL VISIONS: JUSTICE INTO THE TWENTY-FIRST CENTURY}

In light of the above constraints, the question remains: what is the potential for international criminal justice in human rights? In some sense the use of criminal law to enforce human rights is a millennial vision, reaffirmed by the contemporary consensus on establishing a new international institution, the permanent International Criminal Court. The permanent International Criminal Court appears to entrench the postwar tribunal for the end of the century and the next millennium. Yet going beyond the construct at Nuremberg, the statute for the International Criminal Court reveals the dynamic tension discussed here between the politics of universalism and identity politics in international criminal justice. ${ }^{46}$

In the contemporary International Criminal Court, the role of international criminal justice is complex. At mid-century, the International Military Tribunal at Nuremberg articulated an understanding of the rule of law reflecting the consensus of a small number of nation-states. Indeed, at the time, convening the International Military Tribunal was rationalized by the unavailability in occupied Europe of the ordinary nation-state rule of law regime. There was a lack of both sovereignty as it is conventionally understood and working judicial institutions. Whereas in the new global order, the traditional bases for jurisdiction have given way to an expansive, normative agenda. As previously discussed, the expansion of offenses for

45. See generally Van Schaack, supra note 14.

46. Rome Statute, supra note 7. 
which jurisdiction is "universal" points to a similar expansion of transnational consensus. The charter for the new International Criminal Court extends the reach of international criminal law; there is a pronounced move from objective approaches to jurisdiction to more subjective, policybased principles. This is explicit in the expansion of the definition of "crimes against humanity,, 47 and the use of international criminal law both to construct international human rights violations and to represent identity politics. Thus, for example, the new codifications reflect the change afoot in the social and legal construction of rights and rights violations. The turn to international criminal law to protect a pluralist identity politics is evident in the transformation of what counts as "persecution." The Rome Statute includes persecution on political, racial, national, ethnic, cultural, religious, or gender grounds as a crime against humanity. ${ }^{48}$ In addition to establishing identities, the Rome Statute's codification of "crimes against humanity" encompasses crimes of the apartheid regime as well as the repressive policies of military juntas in Latin America and Africa, ${ }^{49}$ an eloquent recognition of profound contemporary political change.

This change is also seen in the Rome Statute's heightened protection of women from sexual violence, with the codification of rape as a crime at several places in the statute. ${ }^{50}$ For example, the U.N. Expert's Report investigating rape and sexual assault in the former Yugoslavia concluded that several different avenues for prosecution were available to address the crime of rape or other sexual assaults. ${ }^{51}$ The definitional requirements of additional material elements, in particular concerning intentionality, create different categories of war crimes. This raises the question of what difference it makes in how the perpetrators of these atrocities are prosecuted; does the resolution of this question depend upon the perceived purpose or purposes of international criminal law? The new codifications allow for

47. See id. art. 7.

48. See id. art. 7, ๆ 1(h).

49. Enforced disappearances and apartheid are now codified as "crimes against humanity." See id. art. 7, ๆศ 1(i), 1(j).

50. "Crimes against humanity" includes "[r]ape, sexual slavery, enforced prostitution, forced pregnancy, . . or any other form of sexual violence of comparable gravity." Id. art. 7, I $1(\mathrm{~g})$. Under the statute, rape is also a war crime, see id. art. 8, I 2(b)(xxii), and potentially a form of genocide. See id. art. 6(b)-(d). See infra notes 51-53.

51. See Annex II, Rape and Sexual Assault: A Legal Study 3, 5-9, in Annexes to the Final Report of the Commission of Experts Established Pursuant to Security Council Resolution 780 (1992), Vol. I, U.N. Doc. S/1994/674/Add.2(Vol.I)/Annex II (1994). 
alternative adjudications of wrongdoing: rape can be prosecuted as a "war crime"; 52 as a "crime against humanity"; 53 or as "genocide." 54 Where rape is prosecuted as a "war crime," the offense constitutes a limit on the waging of war. Where rape is prosecuted as a "crime against humanity," it emphasizes that at war or peace women are part of "humanity." Where rape is prosecuted as "genocide," it emphasizes the intersectionality of genderbased violence with ethnic-based violence and shows how rape can serve as an instrumentality for group destruction. ${ }^{55}$ Ultimately, the availability of alternative adjudications necessitates asking once again, what is the purpose of international criminal justice? Is it the role of prosecutions to best represent past wrongdoing, or is its role to transform the past understandings so as to protect future human rights?

Developments in human rights dating back to the postwar period affirm the notion that there is a growing normative consensus in the expansion of "crimes against humanity." Though punishment may well be ex post and occasional, even this largely symbolic condemnation expresses a sense of international accord. Many of these offenses had already been recognized as human rights violations at customary law, the most heinous known as jus cogens. ${ }^{56}$ There is consensus on these most grave rights offenses, and hence universal jurisdiction. Under the new international rights regime, these offenses have been codified and ratified as conventional law, adding democratic-based legitimacy. For the first time since the immediate postwar period, there are renewed expectations of a shared international normative consensus.

Contemporary developments suggest that international criminal law stands in fragile equipoise, its purposes hanging in the balance. Tension between the expression of the universal and particular is evident in

52. See Rome Statute, supra note 7, art. 8, ๆ 2(b)(xxii).

53. See id. art. 7, ๆ $1(\mathrm{~g})$. See also The Prosecutor v. Jean-Paul Akayesu, Case No. ICTR-96-4-T, pt. 7.7 (visited Feb. 1, 1999) <http://www.un.org/ictr/english/judgements/ akayesu.html>.

54. See Rome Statute, supra note 7, art. 6(b)-(d).

55. See Akayesu, Case No. ICTR-96-4-T, pt. 7.8.

56. See Michael Akehurst, The Hierarchy of the Sources of International Law, 47 Brit. Y.B. Int'l L. 273, 281-82 (1974-75); Vienna Convention on the Law of Treaties, art. 53, opened for signature May 23, 1969, 1155 U.N.T.S. 331 (entered into force Jan. 27, 1980) (defining jus cogens as peremptory norm). For a discussion of these "peremptory norms from which no derogation by treaty is permitted," see Oscar Schachter, International Law in Theory and Practice 342-45 (1991). 
contemporary institutional and statutory developments. Despite lofty universalizing goals of representation of racial, ethnic, and genderized violence, the danger is that the original construction is reaffirmed by the remedy, the equivocal representation of an illiberal politics. ${ }^{57}$ The risk in adjudicating the discrimination-based offense, of emphasizing the racial or ethnic in the offense, is that rights adjudication could reaffirm rabid and unchanging identity politics. Such criminal proceedings would backfire, affirming only the perverse and conservative message of an illiberal state. Illiberal identity politics should be exposed for what it is: a political and social construction.

Accordingly, the new International Criminal Court, established to normalize international criminal justice at the century's end by using the law to respond to atrocities, ultimately raises the recurring question of what is the purpose and role of international criminal law in human rights. Undoubtedly, there is the message, albeit a thin one, of an isolated, discrete adherence to a procedural rule of law. Yet the global human rights regime constitutes a paradoxical normative order. Insofar as it attempts to represent an autonomous norm, free of national and political predicates, it is vulnerable. The sad history of the twentieth century reveals that the protection of human rights is most at risk when it lacks a legal and political matrix of a rule of law state. But the irony is that clearly making this point necessitates the rule-oflaw institutions of the working nation-state. Where there is no critical account of repressive illiberal identity politics, international criminal law can hardly serve to reconcile conflicts, nor to express the essential liberal message of transformation.

57. See generally Butler, supra note 44. 


\section{CONCLUSION}

How to respond to grave injustice? If the modern moment begins with a change in the understanding of the potential of human intervention in recognizing avertible tragedy, the postmodern moment implies recognition of the limits and contingency in its exercise. Yet, historically and in its more contemporary renaissance, international criminal law appears to have a role to play. The globalization of criminal law, though occasional and erratic, has a normative force. Wherever states adjudicate crimes against humanity or other universal offenses, these instantiations represent a consensus upon a rights-based limit on persecutory politics. Nevertheless, this largely symbolic and ex post normative order is lacking, removed from national contexts and thicker political constructs, international criminal processes offer only glimmerings of a transcendent rule of law. The resonance of this particular legal response in the contemporary moment derives from its potential to span universalist and particularist human rights values. Its transformative potential is in moving beyond notions of enduring ethnic conflict to express that what is at stake in the recurring and pervasive communal violence of this century are conflicts that are largely politically constructed, and, therefore, hopefully amenable to change. 
